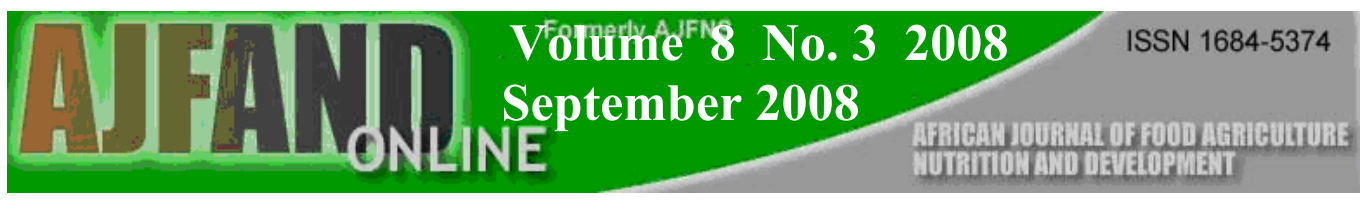

\title{
PRODUCTIVITY OF GOATS AND THEIR CONTRIBUTION TO HOUSEHOLD FOOD SECURITY IN HIGH POTENTIAL AREAS OF EAST AFRICA: A CASE OF MGETA, TANZANIA
}

\author{
${\text { L.O. } \text { Eik }^{1 *} \text {, G.C. Kifaro }}^{2}$, S.M. Kiango ${ }^{2}$, Ø. M. Nordhagen ${ }^{1}$, J. Safari ${ }^{1}$ \\ and L.A. Mtenga ${ }^{2}$
}

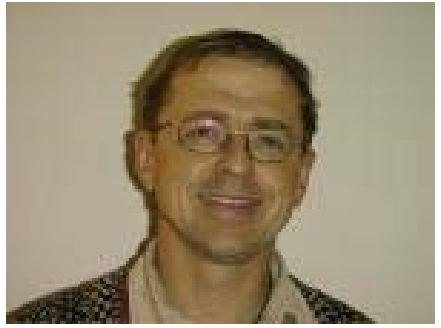

Lars Olav Eik

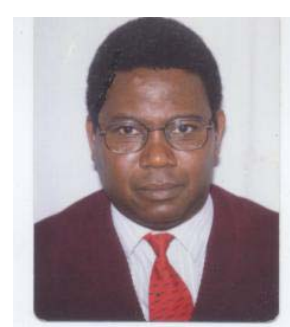

G.C. Kifaro

*Corresponding author email: 1ars.eik@umb.no

${ }^{1}$ Department of Animal and Aquacultural Sciences, Norwegian University of Life Sciences, P.O. Box 5003, N-1432 Aas, Norway, Phone: + 4764965100, Fax: + 4764965101

${ }^{2}$ Department of Animal Science and Production, Sokoine University of Agriculture, P.O. Box 3004, Morogoro, Tanzania 


\section{ABSTRACT}

This study evaluated smallholder production systems in the rural areas of Tanzania and their contribution to household protein supply. Animals kept on the farms were either a combination of dairy and meat goats, dairy goats only, meat goats only or dairy and meat goats in combination with pigs. Vegetable and fruit for sale and maize were the most important produce on the farms. Before introduction of dairy goats, meat goats and pigs were kept on farms with manure being an important output from the latter.

The analysis of the systems was based on data collected on goat production performance in 1996 and a survey conducted in 2003 in four villages in Mgeta Division of Mvomero District, Morogoro, Tanzania. The systems involved pure Small East African goats, Norwegian goats and their crosses. Results indicated that lactation yield increased with increasing proportions of dairy goat genes with the purebred Norwegian dairy goats producing the highest amount of milk. However, these goats had higher kid mortality rate compared to the other genetic groups.

The analysis of the production systems indicated wide variation with respect to protein supply. Estimated amount of animal protein available for human consumption within households was highest in the production system in which dairy goats were kept $(22 \mathrm{~g} /$ person/day) while the system with meat goats only supplied $1 \mathrm{~g} / \mathrm{person} /$ day. It is concluded that the introduction of dairy goats has improved nutrition in Tanzanian households keeping dairy goats.

Intake of animal protein is generally low in villages not keeping dairy goats in Morogoro Region, Tanzania. This research suggests smallholder dairy goat keeping being an effective tool for improving the diet. Livestock products not only provide high-value protein but are also important sources of a wide range of essential micronutrients such as iron and zinc, and vitamins such as vitamin A. In addition to milk and meat, manure is also an important by-product for farmers in this area, and is used to fertilize vegetable plots. For the large majority of people in the world, particularly in developing countries, livestock remains a desired source of food for nutritional value and taste. Multipurpose goats can be recommended introduced, particularly in low-income household in order to maximize food production and security.

Key words: Goat production systems, human nutrition. 


\section{INTRODUCTION}

Household food security is a major concern for many low-income countries such as Tanzania where 22 and $38 \%$ of the people live below the food poverty and basics poverty lines, respectively [1]. Of the children under the age of five in Morogoro, for example, $25 \%$ were underweight and $52 \%$ were stunted [2]. In the same study, about $31 \%$ of the adults were underweight and $10.5 \%$ were stunted. This situation is found in most developing countries in Africa. One way of mitigating the problem of malnutrition is to encourage milk production enterprises among small-scale farmers. Compared to cattle, keeping dairy goats has been found to be a cheap way of improving living conditions of many smallholders $[3,4]$. In this context, dairy goats of the Norwegian breed were introduced in Mgeta in 1988 with the aim of improving household income and nutrition. Other systems, apart from the traditional goat production systems, emerged as a result of the introduction of the improved breed of goats in the area. These production systems and their benefits have not been characterised. A study was, therefore, undertaken to characterise the different goat production systems that have evolved in Mgeta. The main objective of this paper is to provide highlights on productivity of dairy and local goats under different production systems based on smallholder conditions in Mgeta.

\section{MATERIALS AND METHODS}

Mgeta division is located on the western slopes of the Uluguru Mountains in Morogoro, Tanzania, between 1100 and 1750 meters above sea level. The climate in Mgeta is fairly cool, with temperatures ranging between 11 and $23^{\circ} \mathrm{C}$ and an annual rainfall of about $1400 \mathrm{~mm}$. Dry seasons in Mgeta last for approximately four months, usually from June to September [5].

Data on production and reproduction parameters were collected from 235 and 958 recordings for birth weights and milk yields, respectively, accumulated between 1988 and 1996 [6]. In 2003, a total of 75 households were visited and members interviewed using semi-structured questionnaires [7]. In order to assess the contribution of different systems to available household protein, farmers were grouped into four common production systems practiced in the area. These categories were:

Category 1 - dairy and meat goat production $(n=5)$,

Category 2 - dairy goats only $(n=21)$,

Category 3 - meat goats only $(n=15)$,

Category 4 - dairy and meat goat production in combination with pigs $(n=16)$.

A focus group ( 3 women and 5 men) discussion was arranged at the end of the first field work visit for each production system. By using the focus group and participatory rural appraisal (PRA) methods, the participants had a chance to reveal their perspectives in ways that are different from individual interviews [8]. Issues for the group discussion were derived from answers, which needed clarification in the questionnaire survey. Various PRA methods were used. They included direct observation, Community meetings, Gender Analysis, diagramming (Venn diagrams and pie charts), ranking and scoring. Thus the principle of triangulation was achieved

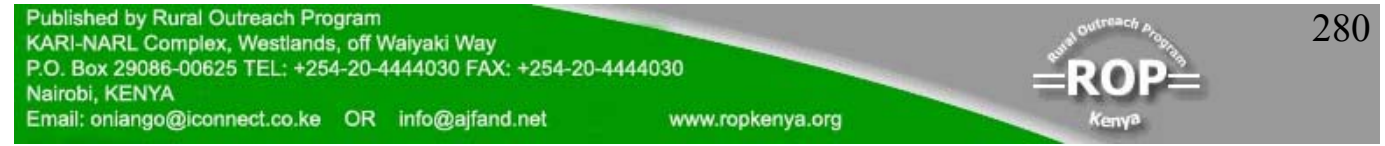


through the research team composition, several PRA methods and several units of observations. To facilitate the PRA process, three groups were formed namely women group, men group and mixed group. Each of the villages namely Langali, Nyandira, Mwalazi and Tchanzema, was represented in each group as much as possible.

Data from the questionnaires and farm records were analysed using SPSS and SAS, respectively $[8,9,10]$. When calculating the contribution of animal protein in the household, it was assumed that the farmers slaughtered and consumed their surplus animals instead of selling them live. The potential meat output was estimated from available data on twinning rates, mortality, slaughter age and growth rates, while table values were used for estimating dressing percentage and protein content of carcass

[11]. Milk recordings were undertaken on a regular basis. Daily yields during the suckling period were obtained by doubling the yield recorded in the mornings. Tools used for gender analysis were Gender roles and Resource access and control. Review meeting and ranking were used to summarise and analyse the data from PRA.

In addition to this information, farmer's records over the period from 1992 to 1996 were also utilised. These data were presented in a thesis at Sokoine Agricultural University and are referred to as 1996 data in the article [6].

\section{RESULTS}

The households in this study consisted of six members, on average and farming was the main source of income for almost all families. Farmers with dairy goats kept from two to four adult milking goats. All dairy farmers practised a partial suckling system, allowing the kids to stay with their dams during the day, but separated at night, for two to three months. During pre-weaning period goats were milked once per day (mornings) while they were milked twice (morning and evening) during post-weaning period. Based on the information collected through the questionnaire survey, milk yield varied between 0.6 and $1.4 \mathrm{~kg}$ per day over a lactation period of 10 months. These values are slightly higher than the 1996 values depicted in Fig 1. 

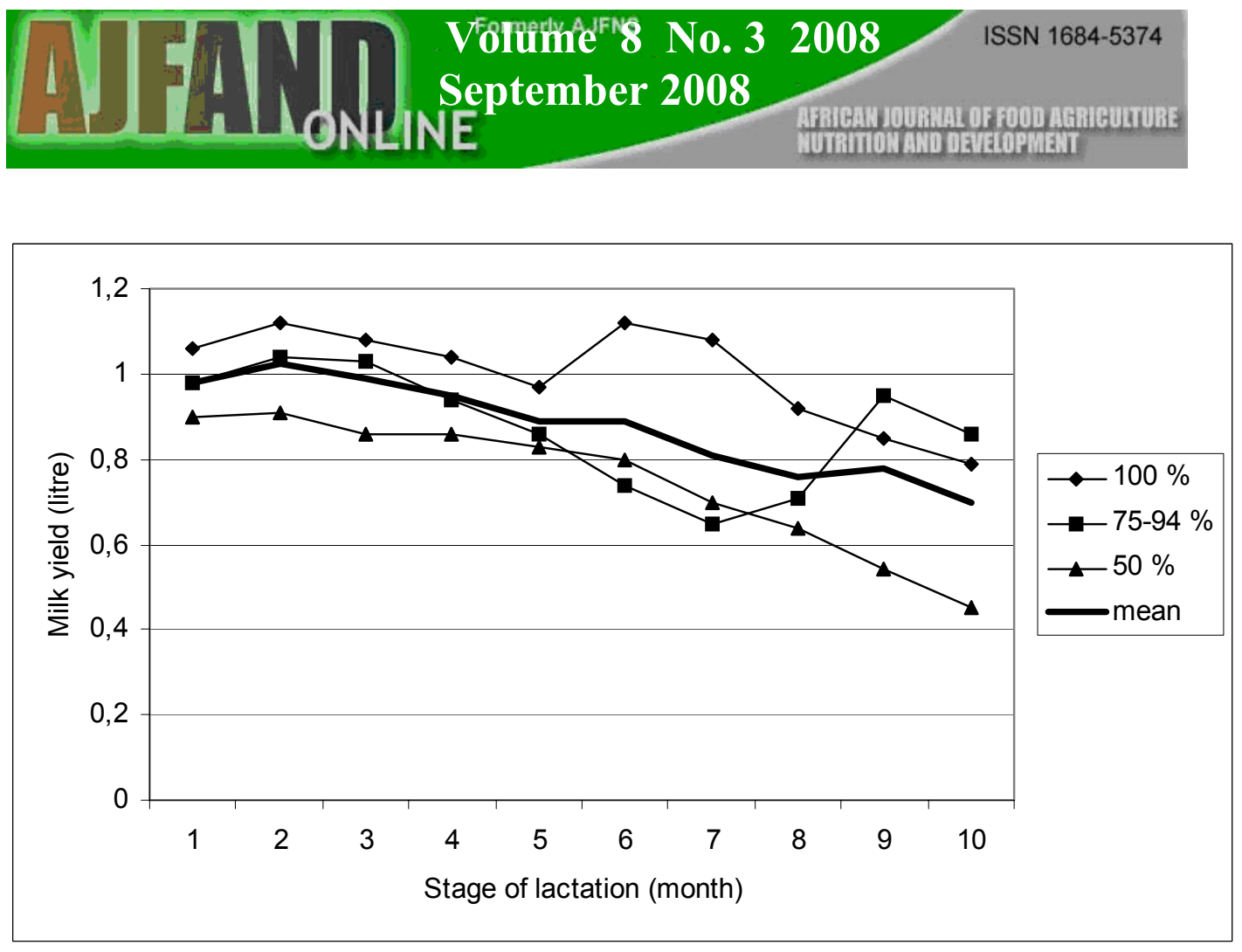

Figure 1: $\quad$ Effect of genotype on milk performance of goats with $100 \%, 75 \%$ or $50 \%$ Norwegian blood

The average milk yield over a ten months lactation period was $1.0 \mathrm{~kg} / \mathrm{day}$ for purebred Norwegian goats, 0.9 and $07 \mathrm{~kg} /$ day for the $75 \%$ and $50 \%$ Norwegian goats, respectively.

Average birth weight of goat kids, which was not affected by level of Norwegian blood, was $2.6 \mathrm{~kg}$. Average body weight (BW) at weaning, adjusted to 90 days of age, was $11.1 \pm 0.15 \mathrm{~kg}$. Male kids were significantly heavier by $1.43 \mathrm{~kg}$ than females, and single born kids were $0.87 \mathrm{~kg}$ heavier than twins. The average growth rate from birth to nine months of age was 85,82 and 65 g per day for the $50 \%, 75 \%$ and $100 \%$ Norwegian blood goats, respectively.

In the 1996 data, the kidding intervals for purebred Norwegian goats $(\mathrm{N}), 75 \% \mathrm{~N}$ and $50 \% \mathrm{~N}$ crosses were found to be 12.8, 10.4 and 11.3 months, respectively. Mortality rates for kids were $7.9 \%$ from birth to three months and $6.9 \%$ from four to nine months of age, respectively. During the period from 1989 to 1993, significant variations were found between years. The losses were mainly due to pneumonia and worm burden.

The average number of goats kept in each household in the 2003 study was $8.2,4.8$, 8.8 and 6.4 , out of which 4.8, 2.6, 4.5 and 5.7 were adult does for the four production systems, respectively. Estimated content of animal protein in human diets ranged between 15 and $22 \mathrm{~g}$ per day per household member available to families keeping dairy goats compared with only $1 \mathrm{~g}$ in families with meat goats only (Table 1 ). When calculating it per adult doe, the differences were even clearer. Families in categories 1 
and 2 with children gave first priority to children regarding consumption of milk. In Category 4 it was the wife in the family who had the first priority.

Goat's meat is popular in Tanzania, and meat from more mature animals above the age of one year is preferred. In Table 1 it is assumed that all surplus animals were slaughtered and consumed within the family. Due to high demand for live animals and the popularity of goat's meat at celebrations, only few animals were used for home consumption in 2002, and hence actual contribution of meat protein in diet was minimal.

If all available goats were used for meat and consumed at home, the estimated output in terms of meat production was higher in dairy goats than in meat goats. Still the contribution of animal protein from meat was small in all categories. The percentage contribution of milk to total animal protein intake in categories with dairy goats ranged from 72 to $79 \%$.

Differences in inputs of labour and feeds between meat and dairy farmers were less than expected. Seventy-four percent of all farmers practised a combination of tethering and stall-feeding of goats. Maize bran was used regularly by dairy goat farmers and occasionally by meat goat farmers. Still the increased labour input in terms of milking and extra feeding seems to be amply justified, especially since alternative labour opportunities are not easily available in the area.

\section{DISCUSSION}

In 1988, a small group of farmers at Mgeta were introduced to dairy goat keeping and provided with animals through a project based at Sokoine University of agriculture. Since then this project has turned out to be a remarkable success with more and more farmers starting up with dairy goats. The availability of milk on a daily basis in the household is probably the main driving force behind the development. In addition to milk, a dairy goat will also provide the same benefits as meat goats, for example meat and manure.

Lactation yield increased with increasing level of Norwegian blood. This was expected since the Norwegian dairy goats have been selected for milk production over a long period of time. However dry matter content of milk was not measured in the present study. In other studies it was found that the pure Norwegian goats had higher yields, but lower DM contents in milk than crosses $[11,21]$. The differences in milk yield between genotypes presented in Figure 1 are therefore expected to be smaller, if calculated on a fat corrected milk basis. Still, purebred dairy goats are preferred by the Mgeta farmers, due to increased milk yield, and perhaps more important, revenues by sale of live animals. At present, price of a purebred yearling ranges from 60 to 100000 Tanzanian shillings, or 51 to 85 USD. This is high in a country where the minimum annual salary for workers is approximately 60000 shilling. 
The average birth weight of $2.6 \mathrm{~kg}$ found in this study was higher than values of 2.1 $\mathrm{kg}$ reported earlier from on-station experiments at Sokoine University of Agriculture, but lower than the normal values of $2.9 \mathrm{~kg}$ for female twin kids reported in Norway $[12,13]$. In Norway, kids with birth weights below $2.5 \mathrm{~kg}$ are considered difficult to rear.

Heat stress imposed on dam in mid-pregnancy resulted in reduced birth weights of kids [14]. Also in smallholder dairy goat units in Tanzania, nutrition of does and rearing of young goats are often sub-optimal compared with practises on Norwegian dairy farms. The low birth weights of kids from Norwegian goats and their crosses in Tanzania may be an explanation for the high mortality rates observed in the dairy goats in Mgeta. Hence, improved nutrition of both mature and young pregnant goats should be underlined.

The $100 \%$ Norwegian goats had lower growth rates at all stages. This confirms previous studies on Norwegian dairy goats and their crosses in Tanzania $[12,15,16]$. In a more recent study, first crosses (50\% Norwegian blood) had significant higher growth rates than purebred local goat kids [17]. Similar positive effects on growth rates of crossbreeding (F1 - crosses) were also found in India and China using Boer goats and in India with Alpine and Toggenburg goats [18, 19, 20].

A kidding interval of one year is normally considered optimal in order to maximize milk yield in semi-intensive and extensive production systems. However, because of high demand and prices of dairy goat kids in Tanzania, farmers tend to reduce this interval.

Kid mortality is usually referred to as mortality of kids from birth to nine months of age. Mortality is a major constraint for improving the efficiency of goat production systems in the dry tropics. The causes of kid mortality are closely related to the systems of production, and include low birth weight, low milk production of the doe, predators, diseases and accidents [21].

High mortality rates of $41 \%$ among the young goats at Sokoine University of Agriculture [22]. Similar high figures are also reported from other places in the tropics $[21,23]$. The latter supports the hypotheses that "The eye of the farmer fattens a calf", meaning that individual farmers give closer care to their stock than institutions, where management is generally poor. This has been amply proved in Mgeta, as well as in other more arid and warmer regions of the country [17].

However the challenges of dairy goat keeping should not be underestimated. Especially purebred dairy goats are susceptible to diseases if not properly managed. On the other, the goat is a small animal and experiences at Mgeta indicate that adequate level of management can be provided or, even by low-income woman headed households.

Nutritional status of children and adults was poor in villages that were not keeping dairy goats in Morogoro Region [2]. This might have been due to lack of animal 
protein in the diets. In the absence of high quality animal protein, plants-based diets require more careful combination of available food to meet requirements of nutrients by children. WHO/FAO gave the following comment on the use of animal products in the human diet: As diet becomes richer and more diverse, the high-value protein that the livestock sector offers improves the nutrition of the vast majority of the world. Livestock products not only provide high-value protein but are also important sources of a wide range of essential micronutrients such as iron and zinc, and vitamins such as vitamin A. For the large majority of people in the world, particularly in developing countries, livestock remains a desired food for nutritional value and taste [24].

In addition to milk and meat, manure is also an important by-product for farmers in this area, which is used to fertilize vegetable plots. Dairy goats were kept confined during night, allowing for collection of dung during this period.

The findings in this study indicate that the introduction of dairy goats has greatly improved food security in the area. Furthermore a change in smallholder management system of goats in Tanzania, from meat production only, to a dual-purpose goat producing both milk and meat, may improve food security for a large number of families.

Furthermore, children are normally given priority when milk is shared among family members, while adult people frequently consume goat meat in parties or festivals. Due to lack of handling facilities such as deep freezers, meat especially from large animals like pigs has to be sold or shared with other households within a day or two. Compared with milk, which is produced on a daily basis, the contribution of meat to food security is relatively low.

The question of how efficient goats are as milk producers depends on how capable they are to produce milk in excess of kids' requirements. The kid rearing system is therefore important. In Tanzania, the dairy goat sector is expanding rapidly, and most purebred goat kids can be sold live for higher prices compared to indigenous kids. When this phase is over, it might however be considered reasonable to slaughter surplus animals at an early age in order to increase available milk for human consumption. Syrstad argued that in most countries in which combined suckling and milking are practised, both food energy and protein are in short supply. Based on calculations for cows, he found that $1 \mathrm{~kg}$ of live weight of a weaned calf is equivalent to about $2.5 \mathrm{~kg}$ of milk as a source of protein for human nutrition, while it corresponds to less than $1.5 \mathrm{~kg}$ of milk in terms of energy [25]. Translated to dairy goats in Tanzania, body weight of a weaned $3-4$ month old goat kid is around $12 \mathrm{~kg}$ and the consumption of milk during the rearing period is about $75 \mathrm{~kg}$. Even without considering mortality, this calculation demonstrates that about four times more protein is available if milk is used for direct consumption instead of meat production. When food is in short supply, it is important to minimize the use of milk in kid rearing and rather emphasise utilisation of forage and by products not suited for human consumption. 


\section{CONCLUSION}

Introduction of dairy goats has resulted in improved diet and food security among smallholder farmers in Mgeta areas of Tanzania. The new technology is adapted and rapidly spreading to other places of the country. Dairy goat keeping seems to be sustainable and profitable; in spite of sub optimal feeding practises and veterinary services. However improved breeding, feeding and management should be encouraged in order to reduce mortality and increase performance of goats. 


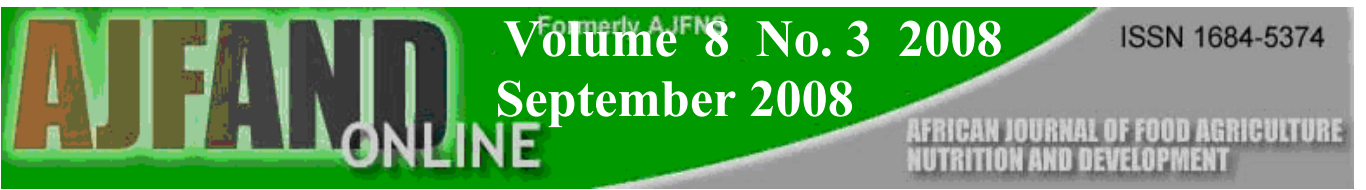

Table 1: Effect of production system on available animal protein for household consumption

Edible amounts of animal protein, g/person/day

Combination of animals $\quad$ Meat $\quad$ Milk $\quad$ Meat + milk $\quad$ Meat + milk

in the household $\quad$ Total $^{1} \quad$ Total $^{1} \quad$ Total $^{1} \quad$ Per adult goat $^{2}$

\begin{tabular}{lcccc}
\hline 1. Dairy + Meat goats & 4.7 & 17.2 & 21.9 & 4.1 \\
2. Dairy goats, only & 3.7 & 14.1 & 17.8 & 5.9 \\
3. Meat goats, only & 1.1 & - & 1.1 & 0.2 \\
4. Dairy + Meat + Pig & 4.2 & 10.8 & 15.0 & 2.6 \\
\hline
\end{tabular}

${ }^{1,2}$ Calculated on basis of total production from the herd and per adult doe

${ }^{3}$ Pigs were kept primarily for manure and protein from meat was not included 


\section{REFERENCES}

1. WHO World Health Organization

Web site: http://www.who.int/countries/tza/background/en/index.httm.

Visited: 19.06.2008.

2. Kinabo J, Msuya J, Nyaruhucha $\mathbf{C}$, Mnkeni A and J Ishengoma Nutritional status of children and adults in Morogoro and Iringa regions. Tanz. Agric.

Research Project Phase Two. Sokoine University of Agriculture, Tanzania, 2003: 307-314.

3. Mtenga LA Feeding of sheep and goats. Research experience. The potential of small ruminants in East and Southern Africa. OAU/IBAR/IDRC, Nairobi, Kenya, 1984: 135-143.

4. Sendalo DSC Tethering of goats in Tanzania: Purpose, and implications with special reference to effects on grazing behaviour and intake. $\mathrm{PhD}$ Thesis, University of Reading, UK, 1995.

5. Mtenga LA and GC Kifaro Dairy goat research and development at Sokoine University of Agriculture - Experiences and future outlook. Improved Dairy Production from Cattle and Goats in Tanzania, occasional Paper Series B, No 11, Noragric/UMB, 1993: 28-40.

6. Kiango SM Studies on factors affecting performance of dairy goats and on socioeconomic aspects of dairy goat production in Tchenzema and Dareda wards in Tanzania. MSc. - thesis, Sokoine University of Agriculture, 1996.

7. Nordhagen ØМ Studies on productivity of dairy and meat goats in high potential areas of East Africa. A case study of Mgeta, Tanzania. MSc. - thesis, Norwegian University of Life Sciences, Norway, 2004.

8. SPSS Statistical Package for Social Sciences user's manual. Chicago SPSS Inc., Chicago, 2000.

9. SAS Statistical Analysis System. SAS/STAT user's guide. Statistical Analysis Institute, INC. Carry, NC.USA, 1998.

10. Bryman A Social Research Methods. Oxford University Press Inc., New York, 2001.

11. Eik LO, Mtenga LA and OHE Olsen Preliminary results on some economic traits in Norwegian and Tanzanian x Saanen goats. PROC 12th. Sci. Conf., Arusha. Tanz. Soc. Anim. Prod., 1985. 
12. Mtenga LA and SM Kiango Some factors influencing performance of dairy goats at Magadu Research Farm. Cattle and goats. Improved Dairy Production from Cattle and Goats in Tanzania. Occasional Paper Series B, No 11. Noragric/UMB, 1993: 89-90.

13. Trodahl S, Skjevdal T and TA Steine Goats in Cold and Temperate Climates. In: Gall C. (Ed). Goat Production. Academic Press INC, 1981: 489-512.

14. Ocfemia GO, Sharun A, Miller HM and JHG Holmes Reduced foetal growth and lactation by does heat-stressed from mid-pregnancy. Small Rumin. Research, 11, 1993: 33-43.

15. Madsen A, Nkya R, Mtenga LA and GC Kifaro Dairy goats for small-scale farmers. Experiences in Mgeta Highland. Tanz. Soc. Anim. Prod. No 17, Sokoine University of Agriculture, Tanzania, 1990: 48-56.

16. Madsen A and LA Mtenga Performance of Norwegian-Tanzania crosses in smallholder husbandry system. Introduced in Upper Mgeta: Preliminary Results. Tanz. Soc. Anim. Prod. No 15, Sokoine University of Agriculture, Tanzania, 1988: 140-158.

17. Safari J, Mushi DE, Mtenga LA, Eik LO, Kifaro GC, Muhikambele VRM, Ndemanisho EE, Maeda Machang'u AD, Kassuku AA, Kimbita EN and M Ulvund A note on growth rates of local goats and their crosses with Norwegian goats at village level in Tanzania. Livestock Research for Rural Development, 2005: Vol. 17, art. 47, Retrieved April12th 2006 from http://www.cipav.org.co/lrrd/lrrd17/4/safa17047.httm

18. Jiabi P, Taiyong C, Jiyun G, Bin P and D Zegao Effects on crossbreeding Boer goats with local goats in China. Book of Abstracts of the $8^{\text {th }}$ International Conference on Goats South Africa, B. 011, 2004: 17.

19. Nimbkar C, Ghalsasi $\mathbf{P}$ and $\mathbf{C}$ Nimbkar Crossbreeding with the Boer goat to improve economic returns from smallholder's goat in India. Proceedings of the $7^{\text {th }}$ International Conference on Goats, 15 - 18 May, Tours, France, 2000: 551 - 556.

20. Nimbkar C, Ghalsasi PM and VS Mane Growth performance of Crossbreds from local goats and Sirohi, Alpine x Sirohi and Toggenburger x Sirohi sires in villages in Maharashtra, India. VI International Conference on Goats, 6 - 11 May, Beijing, China, vol. 1, 1996: $144-147$.

21. Garcia O and C Gall Goats in the Dry Tropics. Goat Production, Gall, C. (Ed.). Academic Press Inc., London, 1980: 515-551.

22. Eik LO, Monrad J and LA Mtenga Health protection in goats. Improved Dairy Production from Cattle and Goats in Tanzania. Occasional Paper Series B, No 9. Noragric/UMB, 1982: 46-53. 


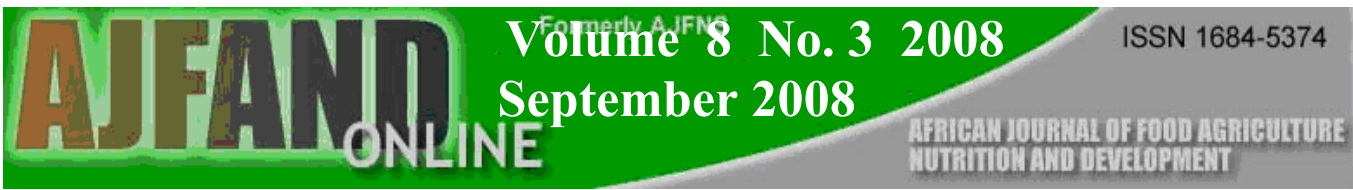

23. Devendra C and M Burns Goat Production in the Tropics, second edition. Commonwealth Agric. Bureau, Slough, UK, 1983.

24. WHO/FAO. Diet, nutrition and the prevention of chronic diseases. WHO Technical Report Series 916, 2003.

25. Syrstad O Evaluation of dual - purpose (milk and meat) animals. World Animal Review 77 (1993/4), 1977: 56 - 59. 